\title{
THE TOXIC EFFECT OF LANGUAGE ON MEDICINE
}

\author{
Michael O'Donnell, Medical author \\ Godalming, Surrey
}

My diagnosis of toxicity is based on the proposition that the language we use when we write or talk about medicine obstructs understanding and distorts our thinking. As a writer, I find it difficult to separate language and thought. And I'm not alone. Two hundred years ago Lavoisier wrote:

'It is impossible to dissociate language from science or science from language, because every natural science always involves three things: the sequence of phenomena on which the science is based, the abstract concepts which call these phenomena to mind; and the words in which the concepts are expressed. To call forth a concept, a word is needed; to portray a phenomenon, a concept is needed. All three mirror one and the same reality.'

GK Chesterton put it more succinctly: 'How can I tell what I think till I see what I say?' So in the beginning comes the word. And the power of the word in medicine is enhanced by the Lohengrin effect ${ }^{(1)}$.

Lohengrin, you will remember, arrives on a swan just in time to save Elsa. He becomes her hero and promises to become her husband provided she doesn't ask him his name. Yet, hardly has the last bar of the wedding march faded when Elsa, displaying the sort of boneheadedness without which legends would have no plots, asks the forbidden question and Lohengrin catches the next swan back up the Scheldt.

This phenomenon of people losing their power once they are named recurs in fables ancient and modern from Rumpelstiltskin, through Turandot, to Last Tango in Paris. In the hands of a doctor, it can be powerful medicine. 'Is this throat of mine serious?' asks the patient. 'No', says the doctor. 'Just pharyngitis'. 'Good', says the patient. The evil has lost its power. It has a name. Some people find that more reassuring than a prescription.

The power that lies in a name comes in handy in general practice. I'm old enough to confess to using it occasionally to manipulate patients who showed me a prescription, or thrust a handful of tablets under my nose, and asked: 'Is this a drug, doctor?' If I thought they'd be better off taking the tablets I answered 'No'; if I thought they'd be better off without them, I answered 'Yes'.

Richard Asher described how doctors use the Lohengrin effect to mislead themselves. In a Lettsomian lecture to the Medical Society of London in 1959 he described how we sometimes assume that something exists because it has a name.

This article is based on a lecture given at the Royal College of Physicians during the College Day, 6 July 1995. It was printed in the Journal of the Royal College of Physicians of London Vol. 29 No. 6 November/December 1995, and is reprinted here by kind permission of the author.
'Take, for example, Pel-Ebstein fever. Every student and every doctor knows that cases of Hodgkin's disease may show a fever that is high for one week and low for the next week, and so on. Does this phenomenon really exist at all? If you collect the charts of 50 cases of Hodgkin's disease and compare them with the charts of 50 cases of disseminated malignant fever, do you really believe you could pick out even one or two cases because of the characteristic fever?

I think it is very unlikely indeed. Yet, if, by the vagaries of chance, one case of Hodgkin's did run such a temperature, the news would soon travel round. "There's a good case of Hodgkin's disease in Galen Ward. You ought to have a look. It shows the Pel-Ebstein fever very well."

The chart might be copied for teaching purposes, or even put in a book. The mere description and the naming of $a$ mythical fever leads inevitably to its occurrence in textbooks ${ }^{\prime 2)}$.

That use of typical as a synonym for atypical echoes a moment from my student days when a surgical registrar, called to see a patient in casualty, told us: 'We must get this chap in for the firm to see. He shows the typical picture and we don't see that very often.'

\section{IN SEARCH OF UNDERSTANDING}

In the early 1980 s I had to write about the lives of John Snow and William Marsden and spent some time reading the papers that they and their contemporaries had written. It was a refreshing experience. The style in which they expressed ideas and passed on information had a clarity and directness that is rare in medical writing today.

In the autumn of 1855 , for instance, Marsden visited hospitals in France and Belgium to see how they treated cancer and, on his return, wrote a report from which I have chosen a characteristic paragraph.

'A hospital devoted to the treatment of cancerous disease seems to me to hold out the only prospect of progress in the treatment of the malady; an institution conducted by those who recognise in medicine and surgery but one art. The records of such an institution are sure, in time, to narrow the field of incurable malignant disease.'

Marsden, like most of his medical contemporaries, expressed himself clearly, choosing simple words to convey his meaning. My fear is that if he'd had the benefit of a modern medical education he would feel he had to write:

'It would seem to the author that only a specialist centre organised on the basis of concentrating its resources solely to 
address the treatment of the malignant disease process could offer a potential for realistic improvements in treatment outcome.

Furthermore, such an institution would be a de facto resource centre under the direct line management of personnel sensitive to the fact that the multifaceted disciplines of medicine and surgery are each essentially manifestations of the same single entity.

Aside from this consideration, the accumulation of followup data by such a resource centre would, at the end of the day, establish new parameters that could be a major determinant of success in reducing the incidence of those manifestations of the malignant disease process which are at present regarded as being resistant to therapy.'

You probably recognise the style because I didn't invent it. I opened a month's supply of journals, spread them across a table, then used phrases plucked randomly from their pages to encode Marsden's original message.

This debasement of the language we use when writing or talking about medicine is a serious matter not just because it erects a barrier to understanding but because, as Lavoisier pointed out, it is a measure of the way we think. Sloppy language is not a product of sloppy thinking; it is sloppy thinking set down for all to see.

\section{CAUSE ...}

When we seek reasons for the decline of medical language since the days of Snow and Marsden, a good place to begin is that moment when some poor creature sits down to write a scientific paper. I say poor creature because he or she isn't always bursting to pass on information but is writing for more solemn reasons, like seeking patronage or preferment. Another paper provides another line on a CV and may help towards a job, a research grant or a merit award. This ridiculous paperchase angers me, not just because there must be better ways of judging people's worth than counting the number of ill-written papers they've published but because it turns the craft by which I earn my living to perverse ends.

Let me explain why. The process of writing, like the process of science, is an attempt to impose order on chaos. Reporters look at a complex event and try to draw from it one or two strands that, set down in a certain way, may convey to their readers an impression of what they thought they saw. A novelist or screen-writer will look at a complex emotion or relationship and try to distil out of it one or two elements that, if portrayed in a certain way, may illuminate our understanding of that emotion or relationship. The process is inevitably reductionist. Yet, in research centres, when people do just a simple piece of work, their reaction is: 'How many papers can we get out of this?'

And another thing. Reporters, novelists, and screenwriters have to be conscious of their audience and use language that will hold its attention. Medical writers are free from such constraint because, as editors shamelessly acknowledge, scientific papers serve the needs of their authors above the needs of their readers ${ }^{(3)}$.

\section{...AND EFFECT}

A sad fact of my life during the 15 years I was editing World
Medicine was that very few doctors seemed capable of expressing themselves in the clear direct language used by Snow and Marsden. I sometimes wondered whether it was a congenital defect, the result of generations of inbreeding between nurses and doctors, but concluded it was really a matter of conditioning. Unless we are lucky, most of us are conditioned to write badly from the day we pick up our first textbook. I found it depressing that sometimes when I commissioned articles from people I knew were bright academics, inspiring teachers, brilliant lecturers, they seemed to react as if I'd invited them to indulge in a ponderous unnatural act. I imagined them retiring to austere writing rooms, donning ceremonial robes fringed with ermine, and sharpening a quill before inscribing their thoughts on parchment. Yet if I suggested they loosen their stays a little, they would switch modes from pompous to patronising and produce a lot of superficial twaddle that they thought had 'the common touch'.

Behind that patronising attitude lies the myth that if you want to express complex ideas clearly you have to write superficially or grossly oversimplify. That's just not true. What you do need to do is to work harder at the writing which, as Lavoisier pointed out, means working harder at the thinking.

We've also been conditioned to accept that we do the work first then 'write it up' afterwards. The very phrase is a giveaway. Experimenters write things up; in the real world where the thinking, and hence the writing, are part of the work, not something to be tacked on at the end - people write things down. The 'writing up' attitude spawns problems that writers would avoid if they just sought to express their thoughts as clearly as they could. As an editor I saw authors in search of readability purge their articles of what they called jargon - or if they were feeling xenophobic what they would call 'Americanisms' - yet leave behind a structure that, compared with their everyday conversation, read like a foreign tongue.

The real barriers to understanding - I know the fashionable word is communication but I prefer understanding - in the language we use to write and talk about medicine are not the long words or the new ideas but the contorted syntax and the bizarre stylistic devices we've been conditioned to accept are part of medical language.

\section{PUTTING ON THE STYLE}

In the years since Marsden and Snow we seem to have created a language all our own and I find it instructive to examine the physiology of the style we have evolved. Let's start with a simple sentence.

\section{A period of unfavourable weather set in.}

This is a sentence that gives no information at all. Rain, hail, sleet, snow, burning sun? A day, a night, a week, 40 days and 40 nights? It tells you nothing but it sounds all right. No alderman would be ashamed to let it trip off his tongue. It could float quite happily across a crowded room. It is, in short, a perfect example of the prose style to which, long ago, I gave the name Decorated Municipal Gothic (DMG) ${ }^{(4)}$.

The essence of DMG is that words are used not because of their meaning but because they are thought to enhance the image of their author or utterer, endowing it with some touch of distinction, some ha'porth of dignity, some hint of 
academic worthiness. This search for enhancement is most easily seen in a form of DMG used by after-dinner speakers. Take the sentence:

\section{He grinned as he pocketed the coin.}

Translated into after-dinner DMG, this becomes:

He showed satisfaction as he took possession of his wellearned reward.

Just as lawyers, when they dress up, feel the need to address one another in a special language - 'If I might be allowed to bring to your Lordship's attention an argument with which your Lordship, with your Lordship's great experience, will be entirely familiar'(5) - so after-dinner speakers who don't know better, assume there is a special language they must put on with their dinner jackets. They usually 'rise with trepidation', 'feel constrained to add', tell us 'it surely behoves us', and say things like, 'We debouched at a local hostelry to partake of a nourishing beverage', when out of their dinner jackets they would say, 'We nipped into a pub for a beer'. But, before we think too harshly of the afterdinner speaker, let's look at our own form of DMG.

Recently when reading a journal I came across this sentence:

This results in a reduction of the proportion of the population that will drive cars.

It's a quite a harmless sentence, easy to understand. Yet I wondered why the author hadn't written: This means fewer people will drive cars, which, in the context, would have had the same meaning. I decided that, like many authors of scientific papers, he probably wouldn't use the second sentence because it doesn't sound 'scientific-paperish' enough, not the sort of language we should use in 'serious' papers. So he abandons simplicity and directness of expression because, like the after-dinner speaker who wants to sound more 'dignified', he wants to sound more 'scientific'.

Medical writers can now draw on a well established DMG vocabulary. To authors, these are words that give their work the right 'scientific' flavour; to readers, they are words that give the work the right unappetising flavour, the right oatmeal consistency, the right degree of reader-deterrence. Here, to give you a taste, are just a few scientifically correct DMG words. You will have no problem constructing a glossary of your own. Just read a paper or two in any journal.

$\begin{array}{ll}\text { DMG } & \text { Translation } \\ \text { Facilitate } & \text { Ease } \\ \text { Numerous } & \text { Many } \\ \text { General public } & \text { People } \\ \text { Public at large } & \text { People } \\ \text { Initial } & \text { First } \\ \text { Remainder } & \text { Rest } \\ \text { Implement } & \text { Do } \\ \text { Utilise } & \text { Use } \\ \text { Locate } & \text { Find } \\ \text { Transmit } & \text { Send } \\ \text { Majority of } & \text { Most }\end{array}$

Let just one of these words into a paper, or a lecture, and the infection will spread with the abandon of organisms that find they have alighted on a nutrient medium. And once the infection is established, alarming secondary effects can appear. The commonest is conjunctionitis.
Enchanted by the sound of their own DMG, writers discover that the words are even more resonant - though only in the author's ears - if they are linked in pairs, particularly if both words have much the same meaning. The effect of putting them together is to give the speech, or prose, a remorseless, soporific rhythm, like waves rolling on to a beach. Here are examples of conjunctionitis I found in just one article.

\section{Future prospect \\ Mutual consensus \\ Forward planning \\ Final conclusion \\ Help and assistance \\ Mutual compromise}

\section{RECENT DEVELOPMENTS}

Medical DMG is not a dead language and readily acquires accretions. Twice in my professional lifetime I have seen sane and intelligent doctors, who'd reached what our mothers used to call 'that dangerous age', embark on passionate affairs with a new language. Like many who embark on such affairs in middle life, they quickly lost all sense of reason and discretion and the arcane vocabulary they created is still inflicted on the young by 'educationalists' who should know better.

The Royal College of General Practitioners has still not fully recovered from the affair that some of its leaders conducted with the language of sociology in the 1960s and 70 s. And some purveyors of medical education - I forbear to call them teachers - still suffer a lingering post-coital tristesse after their energetic entanglement with the language of $1960 \mathrm{~s}$ educationalists. Here, for instance, is a paragraph from a text much praised in the early seventies.

'The individual who is known about by others may or may not know that he is known by them; they in turn may or may not know that he knows or does not know of their knowing about him. Further, while believing that they do not know about him, nonetheless he can never be sure. Also, if he knows they know about him, he must, in some measure at least know about them, but if he does not know that they know about him, he may or may not know about them in regard to other matters.'

That comes from Stigma; Notes on the management of spoiled identity which was recommended reading for GPs and nurses in 1973.

That was the first affair that ended in tears. I now see hospital doctors eager to escape the routine of out-patients, theatre, or laboratory, flirting dangerously with phrases recently described by Michael Leapman in the Observer as 'verbal detritus bred from the half-digested nostrums of the business schools and the self-important hype of the publicrelations industry'.

It's easy to dismiss the new NHS Trustspeak - with its productivity targeting, outward-looking patient-centred perspectives, and so on - as harmless gobbledy-gook. I would suggest it is something much more dangerous because of my conviction that language and thought are inseparable. Here, for instance, is a memorandum to consultants at the Addenbrooke's NHS Trust in Cambridge sent jointly by the chief executive and medical director. 
'You need to be aware that effective 9.00 am on 13th December, the Executive Board has agreed that a "ringfence" shall apply to the bed envelope of each general management grouping across the hospital. Thus the intention is that the Medical grouping, the Surgical grouping and Specialist service grouping for example will consume their own smoke in meeting bed requirements ${ }^{\prime(6)}$.

And here is how a contributor to the Journal for Medical Staff at the East Surrey Hospital explains how the hospital's new Medical Administration Unit will provide the framework to cope with future demands:

'The planning process will consider the volume of each critical resource consumed by each episode and will produce load plans by specialty over an appropriate horizon. It will then aggregate these upwards into an overall resource plan so that capacity and production levels can be set to meet the level of demand'(7).

If that's the explanation, may God protect East Surrey from the actuality.

\section{PRACTICAL PROSE}

Let me stress that I condemn Decorated Municipal Gothic not on literary grounds but on practical physiological ones. We should avoid it not because it is ugly, though it is, but because it gets in the way of understanding. The information or ideas that the writer or lecturer seeks to convey are obscured by the language in which they are expressed.

I coined the label Decorated Municipal Gothic when I saw a sign on the back of a truck in Cheltenham: 'This vehicle is being utilised for highway cleansing purposes'. The handpainted message had such a flourish I was surprised the author hadn't signed it. Yet, as a car driver proved at the moment I found it, the sign didn't work. By the time you'd read it, you'd run into it. And that's the reason why we should purge DMG from our language. Not because we fancy ourselves as literary gents but because it does not work.

\section{THE 'LITERATURE'}

I still blink a bit when I hear people refer to collections of the language we've evolved as 'The literature' - as barefaced a euphemism as you could find. John Maddox, editor of Nature, wrote:

'As things are, too much of what passes for the scientific literature is not literature at all but a way of stringing code words together in such a way that the perpetrators can enjoy the warm glow of knowing that a piece of research has been written up and given a prominent place on the library shelves throughout the world... The immediate interests of the readers that they should be able to read and understand are given only scant attention'(8).

Yet the presses continue to spew out the papers and I recently encountered the statistic that doctors who read one clinical paper every day will, at the end of the year, be 55 centuries behind in their reading of journals. The Cochrane Centre and journal editors are seeking ways to guide clinicians towards useful data but their problem, I'm relieved to say, is not my concern in this lecture.

I am more concerned with our need to restore a literary tradition in medicine, a tradition in which language is used not just to pass on information but to stimulate the imagination, to provoke thought, and to encourage the creativity that too easily gets swamped in a morass of data. During its journey from mystic certainty towards scientific uncertainty, medicine has never quite shrugged off its faith in the inductive approach of Francis Bacon who believed that if man could collect all the information that was available about the world he would completely understand it. And it's remarkable how many doctors still seem to think that the way to apply science to medicine is to act like a vacuum cleaner, collecting vast quantities of data, all carefully observed and punctiliously recorded.

Yet as Peter Medawar wrote while he was director of the National Institute for Medical Research: 'Sciences which remain at Bacon's level of development . . . amount to little more than academic play'. And William Harvey, who was Bacon's doctor, said of his patient: 'He writes philosophy like a Lord Chancellor'. It was clearly the sound of all those vacuum cleaners hoovering away that provoked TS Eliot's oft-quoted lines: 'Where is the understanding we have lost in knowledge? Where is the knowledge we have lost in information?' ${ }^{\prime(9)}$ I have heard those questions repeated in various forms and with increasing desperation over the past 20 years, most recently by Bruce Charlton:

'Factual knowledge of group trials, while necessary, is not sufficient for good practice. The facts must be taken into consideration but, on their own, do not tell the doctor what to do. That decision is a matter of judgement.

Inculcating the power of good judgement is a very different problem from inculcating factual knowledge. Megatrials and epidemiology provide us with a very valuable refinement, but the wellsprings of medical creativity do not seem to lie in the manipulation of statistics' ${ }^{\prime(10)}$.

Medical creativity needs also to concern itself with seeking some understanding of the world in which our patients struggle to survive. We must continue as scientists to investigate and expand our knowledge of that world but in the meantime we can achieve some understanding through art. It is not a literary conceit to suggest, for instance, that those who seek some understanding of the loneliness and the feelings of regret and betrayal that can affect the course of an illness will, in our present state of knowledge, be less likely to find it in accumulated data than in, say, the short stories of William Trevor. And the critic John Naughton, who incidentally trained as an engineer, wrote recently:

'The things that really matter to us - the secrets of the heart, of what it means to be an individual, the depths and heights of human experience - all are accessible, if at all, only through literature and the creative arts. Science has no purchase on them, and precious little to say about them beyond the posturings of reductionists. A knowledge of the biochemistry of the brain tells us nothing about the mind of its owner. And even when the whole of the human genome has been mapped, we will still not know what makes us tick'(II).

I would propose therefore that our modern 'literature' needs:

- More writing that admits us to the company of wise and civilised people who point to things around us and ask 'Have you noticed that?' or 'Have you considered the implications of this?' 
- More writing that is impishly paradoxical or hides its purpose behind straight faced irony, in the hope that it might provoke readers to think afresh about their work and its implications.

- More writing that helps doctors who recognise the need for scientific medicine yet have a secret fear that the job of caring for patients may be taken away from them while they are busy looking after the machines.

- More writing that sharpens our profession's scepticism. Science, after all is a subversive trade that expands our knowledge by questioning our 'certainties'. Those of us who think that most of the troubles in the world are caused by people who have the courage of their convictions would like to hear more from those who have the courage of their doubts.

To achieve these aims, we need to rediscover a language in which we can express our ideas about medicine in a clear and interesting way. That is my proposition and I conclude my case with the testimony of three witnesses. The first is Stendahl:

'I see but one rule: to be clear. If I am not clear, all my work crumbles to nothing'(12). My second is HG Wells: 'I write as I walk because I want to get somewhere; and I write as straight as I can, just as I walk as straight as I can, because that is the best way to get there'(13).

(That is a splendid sentence because not only does it enunciate the principle, it illustrates it in its own construction and endows the message with an image that lingers in our minds.)

My final witness is not a writer but a philosopher, Wittgenstein .
'What can be said at all can be said clearly, and what we cannot talk about we must pass over in silence? ${ }^{\text {(14) }}$.

How blissful that silence would be.

\section{REFERENCES}

1 O'Donnell M. An insiders guide to the games doctors play. London: Gollancz, 1987:109

2 Asher R. Richard Asher talking sense. London: Pitman Medical, 1972:21

3 Shortland M, Gregory J. Communicating science: a handbook. London: Longman, 1991:51

4 O'Donnell M. Looking sideways. World Medicine 1971;7:101

5 Mortimer J. Murderers and other friends. London: Viking $1994 ; 59$

6 Healthcare Management, January 1994;42

7 Bolton M. Synapse: the journal for medical staff at East Surrey Hospital 1994; Issue 5:4

8 Maddox J. Quoted in: Communicating science: a handbook. London: Longman, 1991;51

9 Eliot TS. Choruses from the rock. In: Collected poems 1909-1962. London: Faber, 1962;161

10 Charlton B. Health Watch Newsletter 18 May, 1995:6

11 Naughton J. Observer July 9, 1995

12 Stendhal in a letter to Balzac. Quoted in Writers on Writing. London: Phoenix House, 1948:205

13 Wells HG. Experiment in autobiography. London: Gollancz, 1934;94

14 Wittgenstein L. Tractatus logico-philosophicus. 1922: Preface 